\title{
Jurnal Penelitian Perawat Profesional
}

Volume 2 Nomor 1, Februari 2020

e-ISSN 2715-6885; p-ISSN 2714-9757

http://jurnal.globalhealthsciencegroup.com/index.php/JPPP

\section{EKSTRAK KULIT NANAS SEBAGAI ANTIBAKTERI}

\author{
Imraatul Husniah ${ }^{1}$, Agustina Fadilla Gunata \\ Fakultas Kedokteran, Universitas Lampung, J1. Prof. Dr. Ir. Sumantri Brojonegoro No.1, Gedong \\ Meneng, Kec. Rajabasa, Kota Bandar Lampung, Lampung, Indonesia 35145 \\ *imraatulhusniah@gmail.com (082283609290)
}

\begin{abstract}
ABSTRAK
Penggunaan antibakteri merupakan salah satu cara untuk mengatasi peyakit infeksi. Ekstrak kulit nanas mengandung banyak senyawa kimia yang berpotensi sebagai antibakteri. Senyawa antibakteri tertinggi yang terdapat pada ekstrak kulit nanas yaitu bromelin dan flavonoid. Tujuan literatur review ini adalah untuk mengetahui manfaat ekstrak kulit nanas madu sebagai antibakteri. Artikel ini menggunakan metode studi artikel review, yaitu denganmenggunakan artikel penelitian yang didapat melalui proses pencarian literatur dan buku terkait manfaat ekstrak kulit nanas sebagai antibakteri dari tahun 2009 sampai dengan 2019. Berbagai penelitian eksperimental yang dilakukan menunjukkan bahwa ekstrak kulit nanas madu bermanfaat sebagai antibakteri, baik bakteri gram positif maupun gram negatif. Senyawa kimia yang terkandung pada ekstrak kulit nanas yaitu bromelin, flavonoid, tanin, oxalat, dan pitat dengan kandungan terbesarnya yaitu bromelindan flavonoid. Ekstrak kulit nanas meiliki aktivitas antibakteri yang lebih kuat terhadap gram positif.
\end{abstract}

Kata kunci: aktivitas antibakteri, bromelin, flavonoid, kulit nanas

\section{PINEAPPLE PEEL EXTRACT AS ANTIBACTERIAL}

\begin{abstract}
The antibacterial is usually used to cure the infection. Pineapple peel extract has a lot of chemical compound that has an antibacterial activity. The most antibacterial chemical compound in pineapple peel extract is bromelain and flavonoid. The puspose of this literature review is to determine the benefits of pineapple peel extract as an antibacterial. The method of this article is using article review by searchingthe articles and book related to the pineapple peel extract as antibacterialfrom 2011 to 2019. Various experimentalstudies conducted showed that pineapple peel extract has potential activity as antibacterial, included the positive and negative gram bacteria. The chemical compound in pineapple peel extract is bromelain, flavonoid, tanin, and saponin which the highest chemical compound is bromelain and flavonoid. The gram positive bacterial is more susceptible to pineapple peel extract than the gram negative bacterial.
\end{abstract}

Keywords: antibacterial activity, bromelain, flavonoid, pineapple peel

\section{PENDAHULUAN}

Penyakit infeksi merupakan penyebab tingginya angka kesakitan (morbidity) dan angka kematian (mortality). Tingginya angka kesakitan dan kematian pada penyakit infeksi saat ini bukan hanya di negara berkembang saja, namun juga di negara maju (Christensen et al, 2009). Salah satu obat andalan untuk mengatasi masalah tersebut adalah antimikroba yaitu antibakteri atau antibiotik. Antibiotik merupakan obat yang paling banyak digunakan pada penyakit infeksi yang disebabkan oleh bakteri (Setiabudy, 2012).

Seiring ditemukannya antibiotik, sekarang banyak bakteri yang mengalami resistensi antibiotik. Penyebab utama resistensi 
antibiotik yaitu penggunaannya yang meluas dan irasional sehingga menyebabkan bakteri tidak mati secara keseluruhan namun masih ada yang bertahan hidup. Beberapa bakteri resisten antibiotik sudah banyak ditemukan di seluruh dunia, di antaranya: PenicillinResistant Pneumococci, Multiresistant Mycobacterium tuberculosis dan Methicillin-Resistant Staphylococcus aureus (MRSA)(Asharina, 2017).

Diperlukan adanya usaha agar terjadi resistensi antibiotik. Usaha-usaha tersebut antara lain mengembangan penelitian yang berhubungan dengan mekanisme resistensi, mengontrol penggunaan antibiotik, dan mengembangkan agen antibakteri baru baik sintetis maupun alami(WHO, 2018).

Indonesia merupakan negara penghasil nanas terbesar kelima di dunia setelah Thailand, Costa Rica, Brazil, Filipina(UNCTAD, 2016) dan provinsi Lampung sendiri memberikan kontribusi terbesar terhadap produksi nanas di Indonesia(Kementan RI, 2016). Varietas utama yang terdapat di Indonesia yaitu Smooth Cayenne atau yang lebih dikenal sebagai nanas Madu dan Queen(Hadiati dan Indriani, 2009).

Industri makanan di Indonesia mengolah buah ini menjadi produk baru dan selanjutnya menghasilkan limbah yang menyebabkan masalah lingkungan. Kirakira, satu berat total buah nanas madu adalah 1050 gram dimana 229 gramnya (21,9\%) adalah limbah kulit(Mulyono, 2013). Untuk mengurangi limbah kulit nanas tersebut, pengolahan ke produk yang berharga menggunakan teknik yang ramah lingkungan sangat diperlukan(Saraswaty et al, 2016).

Kulit nanas banyak mengandung flavonoid dan bromelin(Punbasayakul et al, 2018). Selain itu kulit nanas mengandung senyawa tanin, oxalat, dan pitat (Dabesor et al, 2017). Flavonoid dapat menyebabkan penghambatan terhadap sintesis asam nukleat. Selain itu flavonoid juga menghambat metabolisme energi dari bakteri. Oleh karena itu flavonoid merupakan komponen antibakteri yang potensial(Xie et al, 2015). Bromelin merupakan enzim proteolitik yang dapat memecah molekul protein. Bromelin dapat memutus ikatan protein pada bakteri sehingga dapat menghambat pertumbuhan bakteri(Amini et al, 2018). Aktivitas, spesifisitas dan produksi dari enzim bromelin lebih banyak pada bagian kulit nanas dibandingkan dengan buah dan batang(Mohapatra et al, 2013).

Berdasarkan uraian di atas, dapat diketahui bahwa diperlukan adanya usaha yang dilakukan agar tidak terjadi resistensi antibiotik. Salah satu usaha yang dapat dilakukan adalah mengembangkan antibakteri baik sintetis maupun alami. Penelitian ini penting dilakukan sebagai salah satu usaha yang dapat dilakukan untuk mengembangkan antibakteri alami dan juga dari kandungan yang dimilikinya kulit nanas berpotensi sebagai antibakteri.Oleh karena itu, literatur review ini bertujuan untuk mengetahui manfaat ekstrak kulit nanas sebagai antibakteri.

\section{METODE}

Penulisan ini menggunakan metode studi artikel review. Sumber pustaka yang digunakan dalam menyusun literatur ini menggunakan buku pedoman dan melalui proses literatur searching terkait manfaat ekstrak kulit nanas dan antibakteri. Tahun penerbitan artikel yang digunakan adalah tahun 2009 sampai tahun 2019. Jumlah artikel yang digunakan adalah sebayak 27 artikel.

\section{HASIL}

Punbasayakul et al (2018) telah meneliti aktivitas antibakteri ekstrak kulit nanas terhadap bakteri Staphylococcus aureus, Bacillus cereus, Escherichia coli, Salmonella typhimurium. Didapatkan diameter zona hambat ekstrak etanol 96\% kulit nanas dengan konsentrasi $0,5398 \mathrm{~g} / \mathrm{ml}$, $0,2699 \mathrm{~g} / \mathrm{ml}$, dan $0,1349 \mathrm{~g} / \mathrm{ml}$ terhadap bakteri Staphylococcus aureus yaitu 7,50 
mm, 7,00 mm, 10,33 mm. Pada konsentrasi yang sama, diameter zona hambat ekstrak kulit nanas terhadap bakteri Bacillus cereus yaitu $7 \mathrm{~mm}, 8,17 \mathrm{~mm}, 10,50 \mathrm{~mm}$. Diameter zona hambat ekstrak kulit nanas terhadap bakteriEscherichia coli yaitu $7 \mathrm{~mm}, 7,5$ $\mathrm{mm}, 8,33 \mathrm{~mm}$. . Diameter zona hambat ekstrak kulit nanas terhadap bakteriSalmonella typhimurium. Dengan konsentrasi yang sama yaitu $0 \mathrm{~mm}, 7,67$ $\mathrm{mm}, 9,33 \mathrm{~mm}$. Uji diameter zona hambat dilakukan dengan metode disk diffusion test. Sementara itu konsentrasi hambat minimum ekstrak kulit nanas terhadap bakteri yang sama berturut turut yaitu sebesar $\quad 0,0084 \mathrm{~g} / \mathrm{ml}, \quad 0,0084 \mathrm{~g} / \mathrm{ml}$, $0,0168 \mathrm{~g} / \mathrm{ml}$, dan $0,0084 \mathrm{~g} / \mathrm{ml}$ dan konsentrasi bunuh minimumnyayaitu $0,0675 \mathrm{~g} / \mathrm{ml}$, tidak terdeteksi pada bakteri Bacillus cereus, $\quad 0,0675 \mathrm{~g} / \mathrm{ml}$, dan $0,0675 \mathrm{~g} / \mathrm{ml}$. Dari penelitian ini disimpulkan bahwa bakteri gram positif lebih memiliki sifat antibakteri daripada bakteri gram negatif(Punbasayakul et al, 2018).

Pada penelitian Omorotionmwan et al (2019), dilakukan uji diameter zona hambat ekstrak etanol $80 \%$ kulit nanas dengan konsentrasi 5\%, 10\%, dan 50\% pada bakteri Staphylococcus aureus, Escherichia coli, Streptococcus faecalis, Pseudomonas aeruginosa. Uji diameter zona hambat dilakukan dengan metode sumuran. Didapatkan hasil bahwa konsentrasi ekstrak kulit nanas yang menghambat pertumbuhan bakteri yaitu $50 \%$ dengan diameter zona hambat sebesar $16 \mathrm{~mm}, 13 \mathrm{~mm}, 16 \mathrm{~mm}$, dan $14 \mathrm{~mm}$. Sedangkan konsentrasi hambat minimal dan konsentrasi bunuh mnimalnya terdapat pada konsentrasi $50 \%$ pada keempat bakteri tersebut kecuali Pseudomonas aeruginosa. Dapat dilihat bahwa bakteri gram positif memiliki diameter zona hambat yang lebih besar daripada bakteri gram negatif(Omorotionmwan et al, 2019).

Rini et al (2017) menyebutkan, daya hambat hand sanitizer ekstrak kulit nanas sebagai antibakteri Staphylococcus aureus pada konsentrasi $1,5 \%$ yaitu sebesar 15 $\mathrm{mm}$. Uji diameter zona hambat dilakukan dengan metode disk diffusion test(Rini et al,
2017). Pada penelitian yang dilakukan oleh Wirhaningtyas et al (2018), KHM yang dilakukan dengan metode dilusi ekstrak kulit nanas terhadap Staphylococcus aureus yaitu sebesar 1,56\% (Wirhaningtyas et al, 2018). Pada penelitian yang dilakukan oleh Loon et al (2018) konsentrasi hambat minimum ekstrak nanas yang dilakukan dengan metode dilusi terhadap Staphylococcus aureu (Loon et al, 2018)yaitu $1,56 \%$

\section{PEMBAHASAN}

Antibiotik atau antibakteri merupakan obat yang paling banyak digunakan pada penyakit infeksi yang disebabkan oleh bakteri (Setiabudy, 2012). Antibiotik dapat diklasifikasikan berdasarkan mekanisme kerjanya. Klasifikasi pertama yaitu antibakteri yang menghambat sintesis atau merusak dinding sel. Contohnya yaitu betalaktam (penisilin, sefalosporin, monobaktam, karbapenem, inhibitor betalaktamase). Klasifikasi yang kedua yaitu antibakteri yang memodifikasi atau menghambat sintesis protein antara lain yaitu aminoglikosid, kloramfenikol, tetrasiklin, makrolida (eritromisin, azitromisin, klaritromisin), klindamisin, dan musiprosin. Kemudian ada antibakteri yang menghambat enzim-enzim esensial dalam metabolisme folat antara lain trimetroprim dan sulfonamid dan mempengaruhi sintesis atau metabolisme folat antara lain kuinolon dan nitrofurantoin (Permenkes, 2011).

Tanaman nanas dapat tumbuh pada keadaan iklim basah maupun kering. Tanaman nanas dapat tumbuh baik di daerah tropis yang terletak antara $25^{\circ}$ lintang utara sampai $25^{\circ}$ Lintang selatan dengan ketinggian tempat 100-800 m dari permukaan laut. Pada umumnya tanaman nanas toleran terhadap kekeringan serta memiliki kisaran curah hujan yang luas sekitar 1.000-1.500 mm per tahun. Terdapat beberapa golongan varietas nanas diantaranya yaitu Smooth Cayenne, Queen, RedSpanish dan Abacaxi (Joy dan Anjana, 2013). Varietas utama yang terdapat di Indonesia yaitu Queen dan Smooth Cayenne, yang lebih dikenal 
sebagai nanas Madu. (Hadiati dan Indriyani, 2008).

Kulit nanas merupakan produk hasil olahan industri yang terdiri dari sisa daging buah, kulit, dan kulit terluar. Jika kulit nanas tidak dimanfaatkan bisa menyebabkan pencemaran lingkungan. Kulit nanas merupakan sumber potensial untuk pemanfaatan dari senyawa bioaktif yang terkandung didalamnya, terutama enzim Bromelin (Ketnawa et al., 2009).

Kulit nanas banyak mengandung bromelain. Selain itu, kulit nanas juga mengandung flavonoid (Punbusayakul, 2018), tanin, oxalat, pitat, dan glikosida yang berperan sebagai antibiotik (Dabesor et al., 2017). Flavonoid merupakan senyawa golongan fenol yang paling banyak ditemukan di alam (Tungmunnithum et al., 2018). Kandungan flavonoid dapat menyebabkan penghambatan terhadap sintesis dinding sel. Oleh karena itu flavonoid merupakan komponen antibakteri yang potensial.

Kulit buah nanas memiliki senyawa flavonoid yang bersifat desinfektan dan sangat efektif dalam menghambat pertumbuhan bakteri gram positif. Hal ini disebabkan karena flavonoid bersifat polar sehingga lebih mudah menembus lapisan peptidoglikan yang juga bersifat polar pada bakteri gram positif daripada lapisan lipid yang non polar. Pada dinding sel bakteri gram positif mengandung polisakarida (asam trikoat) yang merupakan polimer larut dalam air, yang berfungsi sebagai transfer ion positif untuk keluar masuk. Sifat larut itulah yang menunjukan bahwa dinding sel gram positif bersifat lebih polar. Setelah masuk, flavonoid segera bekerja menghancurkan bakteri dengan cara mendenaturasi protein yang dapat menyebabkan aktifitas metabolisme. Sel bakteri berhenti karena semua aktifitas metabolisme sel bakteri dikatalisis oleh suatu enzim yang merupakan protein. Berhentinya aktifitas metabolisme ini akan mengakibatkan kematian sel bakteri (Suerni et al., 2013).
Bromelin merupakan enzim proteolitik yang menghasilkan reaksi katalisis dan hidrolisis dengan memecah ikatan peptida pada protein bakteri. Hal ini menyebabkan bromelin dapat menghambat pertumbuhan bakteri (Amini et al., 2018). Bromelin juga dapat diperoleh dari hampir semua bagian tanaman nanas (Ananas comosus [L]Merr.) baik dari tangkai, kulit, daun, buah, maupun batang. Enzim ini menguraikan protein dengan jalan memutuskan ikatan peptida dan menghasilkan protein yang lebih sederhana. Bromelin merupakan unsur utama dari nanas yang penting dan berguna dalam bidang farmasi dan makanan olahan (pengempuk daging). Selain itu enzim bromelin sering dimanfaatkan sebagai bahan kontrasepsi KB untuk memperjarang kehamilan (Praveen et al., 2014).

\section{SIMPULAN}

Ekstrak kulit nanas mengandung senyawa utama yaitu bromelin dan flavonoid yang mempunyai potensi sebagai antibakteri.Ekstrak kulit nanas meiliki aktivitas antibakteri yang lebih kuat terhadap gram positif.

\section{DAFTAR PUSTAKA}

Amini A, Setiasih S, Handayani S, Hudiyono S, Saepudin E. 2018. Potential Antibacteial Activity of Partial Purified Bromelain from Pineapple Core Using Acetone and Ammonium Suphate Againts Dental Caries-Causing Bacteria. AIP Conference Proceedings 2023. Universitas Indonesia.

Asharina I. 2017. Resistensi Antibiotik Indonesia-Tak Usah Dulu Bermain Undang-Undang. Working Paper. Bandung: Institut Teknologi Bandung.

Christensen KLY, Holman RC, Steiner CA, Sejvar JJ, Stoll BJ, Schonberger LB. 2009. Infectious Disease Hospitalizations in the United States. Oxford Academic. 49(7): 1025-35. 
Cusine TPT, Lamb AJ. 2005. Antimicrobial Activity of Flavonoids. Int $\mathrm{J}$ of Antimicrob Agents. 25(5): 343-56.

Dabesor AP, Asowata AM, Umoiette P. 2017. Phytochemical Compositions and Antimicrobial Activities of Ananas comosus Peel (M.) and Cocos nucifera Kernel (L.) on Selected Food Borne Pathogens. AJPB .2(2):73-76.

Hadiati S, Indriani NLH. 2008. Petunjuk Teknis Budidaya Nenas. Solok: Badan Penelitian Tanaman Buah Tropika.

Hadiati S, Indriani NLH. 2009. Petunjuk Teknis Budidaya Nenas. Solok: Badan Penelitian Tanaman Buah Tropika.

Joy RP, Anjana R. 2013. Pineapple Varieties. [Technical Report]. Tersedia dari: https://www.researchgate.net/publica tion/306034709

Kementrian Pertanian RI. 2016. Outlook Nenas. [Online]. Tersedia dari https://epublikasi.sekjen.pertaian.go.i d

Ketnawa S, Chaiwut P, Rawdkuen S. 2009. Pineapple Waste: A Potential Source for Bromelain Extraction. Food Bioprod Process. 90(3):385-391.

Loon YK, Satari MH, Dewi W, 2018. Antibacterial Effect of Pineapple (Ananas comosus) Extract Towards Staphylococcus aureus. Padjajaran Journal of Dentistry. 30(1):1-6.

Mohapatra A, Rao VM, Ranjan M. 2013. Comparative Study of The Increase Production and Characteriation of Bromelain From the Peel, Pulp \& Stem Pineapples. IJOART. 2(8): 24979.

Mulyono N, Elisabeth R, Moi JG, Valentine BO, Suhartono MT. 2013. Quantity and Quality of Bromelain in some Indonesian Pineapple Fruits. IJABPT. 4(2):235-40.

Omorotionmwan FO, Ogwu HI, Ogwu MC. 2019. Antibacterial Characteristics and Bacteria Composition of Pineapple (Ananas comosus [Linn.] Merr.) Pell and Pulp. Food and Health. 5(1):1-11.

Pertaturan menteri kesehatan Republik IndonesiaI Nomor 2406/MENKES/PER/XII/2011

Praveen NC et al. 2014. In Vitro Evaluation of Antibacterial Efficacy of Pineapple Extract (Bromelain) on Peridontal Pathogens. J Int Oral Health. 6(5):96-98.

Punbasayakul N, Samart K, Sudmee W. 2018. Antimicrobial Activity of Pineapple Peel Extract. Proceeding of Innovation of Functional Foods in Asia Conference; 2018 April 24; Phayao. Thailand. Thailand:IFFA.

Putra BP. 2016. Uji Aktivitas Antimikroba Ekstrak Nonggol Nanas terhadap Methicillin-Resistans Staphylococcus aureus [Skripsi]. Surabaya: Universitas Airlangga.

Rini ARS, Supartono, Wijayati N. 2017. Hand Sanitizer Ekstrak Kulit Nanas sebagai Antibakteri Staphylococcus aureus dan Escherichia coli. Indonesian Journal of Chemical Science. 6(1):61-6.

Saraswaty V, Risdian C, Primadona I, Andriyani R, Andayani DGS, dan Mozel T. 2016. Pineapple Peel Waste as a Potential Source of Antioxidant Compunds. IOP Science. 60(1):1-5.

Setiabudy, R. 2012. Farmakologi dan Terapi Edisi 5. Dalam S. S. Gunawan editor (penyunting). Jakarta: Badan Penerbit Fakultas Kedokteran Universitas Indonesia. 
Suerni E, Alwi M, Guli MM. 2013. Uji Daya Hambat Ekstrak Kulit Nanas (Ananas comosus L. Merr), salak (Salacca eduilis Reinw.) dan Mangga Kweni (Mangifera odorata Griff.) terhadap Daya Hambat Staphylococcus aureus. Biocelebes. 7(1):1-8.

Tungmunnithum D, Areeya T, Apinan P, Aujana Y. 2018. Flavonoids and Other Phenolic Compounds from Medicinal Plants fot Pharmaceutican and Medical Aspects: An Overview. Medicines. 5(93):1-16.

UNCTAD. 2016. PINEAPPLE. Geneva: An INFOCOMM Commodity Profile.
WHO. 2018. Antibiotic Resistance. [Fact Sheets]. Tersedia dari https://www.who.int/news.

Wirhaningtyas I, Waworuntu O, Juliatri. 2016. Uji Konsentrasi Hambat Minimum (KHM) Ekstrak Kulit Nanas (Ananas comosus L) terhadap Staphylococcus aureus. Jurnal Ilmiah Farmasi UNSRAT. 5(4):18-24.

Xie Y, Yang W, Chen X. 2015. Antibacterial Activities of Flavonoids: Structure-Activity Relationship and Mechanism. Curr Med Chem. 22(1):1-10 